\title{
Study of Oil-Contaminated Soils Phytotoxicity During Bioremediation Activities
}

\author{
Yuriy Sivkov' ${ }^{1}$ Artur Nikiforov ${ }^{1 *}$ \\ 1 Department of Technospheric safety, Tyumen Industrial University, Tyumen, Russia \\ * Corresponding author's e-mail: arhont607@gmail.com
}

\begin{abstract}
This work is devoted to studying the dynamics of changes in phytotoxicity of oil-contaminated meadow soils in the process of microbial bioremediation. The research was conducted under laboratory and field conditions. Winter rye (Secále cereále) was selected as the test object. In order to assess the degree of toxicity in the laboratory, the indicators of seed germination - germination rate and germination energy-were determined. In a field experiment, the ecological state of oil-contaminated soils was evaluated by the germination rate and the amount of aboveground plant biomass. The research results showed that the content of petroleum products significantly affected the percentage of germination of rye seeds. There are differences in the size of seedlings for different experimental schemes: in all tests, the average height of cleoptila on polluted soil was less than on unpolluted soil, but at the same time it varied for different experimental bioremediation schemes. The use of potassium humate and modified vermiculite as additives significantly reduced the toxicity of the oil-contaminated soil.
\end{abstract}

Keywords: soil, pollutants, oil contamination, bioremediation, Secále cereále.

\section{INTRODUCTION}

Bioremediation is a technology for remediation of contaminated areas, in which microorganisms are used to decompose pollutants into less toxic forms (Kazuya, 2001; Andreoni, Gianfreda, 2007; Robles-Gonzalez et al., 2008; Lakshmi et al., 2013). For example, organic pollutants such as petroleum hydrocarbons are converted into carbon dioxide and water during bioremediation, which are harmless metabolites (Seo et al., 2009). Bioremediation is a method of cleaning up pollution by enhancing the same biodegradation processes that occur under natural conditions ( $\mathrm{Lu}$ et al., 2012; Lakshmi et al., 2013).

The changes in the composition and content of petroleum hydrocarbons in the soil during bioremediation lead to the changes in the biological toxicity of the soil. Some oil metabolic compounds, such as aromatic ketones, aldehydes, carboxylic acids, fatty acids, and esters, also contribute to the biotoxicity of oil pollutants (Lee, 2003).
The biotests for toxicity to plants provide unique advantages compared to the tests on animals or microbes. Wang (1991) suggested that the general benefits of plant toxicity testing include:

- ready for testing in the sense that seeds can be purchased in bulk, and the shelf life of most of them is a year or more;

- ready activation for testing (seed germination); - minimal maintenance costs between tests.

These characteristics make the plant the most suitable for the assessment of contaminated soils.

Higher plants are often used in the toxicity tests for oil-contaminated soil, since they are most susceptible to oil and petroleum products (Masloboev, Evdokimova, 2012). The choice of plants as test objects depends on such factors as the type of soil, the nature of pollution, climatic conditions, etc. In their work, Pawluśkiewicz et al. (2020) determined the effect of soil pollution with diesel fuel on the early development of three legume plant species (Medicago lupulina L., Lotus corniculatus L., Trifolium repens L.). The 
authors proved that the studied species have different tolerance to the petroleum products in the soil and demonstrate different protective mechanisms under stressful conditions.

Buluktaev (2019) proved that radish is a good indicator of oil pollution, and the relatively short growing season allows using radish for laboratory experiments. Płaza et al. (2005) used six higher plant species (Secale cereale L., Lactuca sativa L., Zea mays L., Lepidiumsativum L., Triticumvulgare L., Brassica oleracea L.) for the biotests based on seed germination and root elongation, which showed different sensitivity to oil pollution.

Dry plant seeds, when at rest, can withstand harsh environmental conditions without loss of viability. However, when wet and under favorable conditions, plant seeds undergo rapid changes metabolism, nutrient transport, and cell division occur (Mayer and Poljakoff-Mayber, 1982), and during this period, sprouted seeds become very sensitive to the environmental stress. For this reason, seed germination and germination energy are the most common indicators for assessing phytotoxicity.

\section{MATERIALS AND METHODS}

The object of research involved meadow soils of the subtaiga zone in the South of the Tyumen region. The soil of the studied territory was characterized as meadow leached medium-low-humus medium-loamy. The soil-forming rocks are cover loams and clays.

The results of agrochemical analysis showed that the studied soil is characterized by a high humus content of $5-7 \%$; the content of mobile phosphorus is average and varies within 53-68 mg / kg; the potassium content is low and is about $51-70 \mathrm{mg} / \mathrm{kg}$; nitrates are practically absent, less than $2.8 \mathrm{mg} / \mathrm{kg}$. The $\mathrm{pH}$ of the medium in the upper part of the profile is neutral $\mathrm{pH} \mathrm{KCl} 6.5$.
At the first stage of the experiment, phytotoxicity was evaluated in the laboratory. The study of phytotoxicity of oil-contaminated soils was carried out using various schemes of microbial bioremediation, presented in Table 1.

When planning the experiments, the same level of oil pollution was assumed at all the sites under study (approximately $5.0 \%$ of the soil mass). The oil dose for contamination was calculated taking into account the soil compaction density and the oil density at a wetting depth of $20 \mathrm{~cm}$. The amount of the introduced bacterial preparation, which is an association of oil-destroying bacteria (Bacillus, Atherobacter, Rhodococcus, Pseudomonas), was 0.03 liters per site. The preparation was diluted with water from a natural source in such a way and in such a ratio that the resulting solution was evenly distributed over the entire planned area. The amount of lime applied was determined based on the acidity of the salt extract of the studied soil (the norm was $0.1 \mathrm{~kg} / \mathrm{m}^{2}$ ). The $\mathrm{C}$-Verad sorbent (modified vermiculite) was added in the amount of $0.1 \mathrm{~kg}$ per $1 \mathrm{~m}^{2}$. The amount of potassium humate was $30 \mathrm{ml} / \mathrm{m}^{2}$, diluted in a ratio of $1: 300$ with water.

On the basis of the analysis of literature data (Muratova et al, 2008; Muratova et al, 2010; Nõlvak et al., 2013), winter rye (Secále cereále) was selected as the most suitable bioindicator for assessing the soil phytotoxicity at various stages of bioremediation of meadow soils in the south of the Tyumen region. This inexpensive and easy-togrow plant is superior to all other cover crops in infertile, sandy or acidic soil or poorly prepared land. Rye reaches its highest fertility when the soil $\mathrm{pH}$ is above 6.0, preferably 6.5. It is widely adapted, but grows best in cool, temperate zones. Seeds begin to germinate at a temperature of $0.5-2^{\circ} \mathrm{C}$.

Vegetative vessels with a capacity of $2000 \mathrm{ml}$ were used for the experiment. For each plot, 100 seeds were selected, which were pre-checked visually to make sure that they were of uniform size and not damaged. Then, the seeds were washed twice with ethanol (70\%). The seeds were sown

Table 1. Schemes of microbial bioremediation

\begin{tabular}{|l|c|c|c|c|}
\hline \multicolumn{1}{|c|}{ Experiment scheme } & Oil & Bactreparation & Lime & Sorbent \\
\hline Uncontaminated control & - & - & - & - \\
\hline Contaminated control & + & - & - & - \\
\hline S1 & + & + & + & - \\
\hline S2 & + & + & + & - \\
\hline S3 & + & + & + & - \\
\hline
\end{tabular}


in the soil on days 12 and 40 from the beginning of the experiment. The rye seeds sprouted at room temperature of $20 \pm 2^{\circ} \mathrm{C}$.

In order to assess the degree of toxicity in the laboratory, the indicators of seed germination germination rate and germination energy-were determined. Seed germination was calculated as the proportion of sprouted seeds, expressed as a percentage of the total number of seeds taken for germination. The germination energy was calculated as the number of seeds sprouted during the first three days, expressed as a percentage of the total number of seeds taken for germination. The studies were carried out in three-fold repetition.

The second stage consisted of conducting field research. Four plots of $1 \mathrm{~m}^{2}$ each were allocated for the experiment. The scheme of the field experiment corresponded to the scheme of laboratory research. The ecological state of oilcontaminated soils was assessed by the germination rate and the amount of the aboveground plant biomass.

At all stages of research, the residual content of oil products was assessed using fluorimetry methods.

\section{RESULTS AND DISCUSSION}

The results of the research showed that the soil samples, 12 days after the experiment, having a residual content of petroleum products from 5010 to $7224 \mathrm{mg} / \mathrm{kg}$, have an inhibitory effect on rye grains, reducing the speed of seed germination and plant growth and shifting the growth phases of sprouts. This is characterized by low values of germination energy - during the first three days on the oil-contaminated control, it was only $1 \%$, while the germination rate was $12 \%$. The highest values of germination were observed in vegetation vessels $\mathrm{S} 2$ and S3 -40 and $45 \%$, respectively, but the germination energy in the S3 sample is 2.8 times higher than in the S2 sample. The germination rate of the Secále cereále seeds in uncontaminated soils used as a control was $92-94 \%$, and the germination energy was $88-92 \%$.

In the soil samples 40 days after the start of the experiment, the residual content of petroleum products varied from $2644 \mathrm{mg} / \mathrm{kg}$ to $5666 \mathrm{mg} / \mathrm{kg}$ in the S2 sample and the oil-contaminated control, respectively. This reduction in oil pollution has had a positive impact on the seed growth rates, especially on the germination energy. In the growing vessel S3, this indicator increased from 14 to $38 \%$, and in the vessel S2-from 5 to $16 \%$. The greatest increase in germination (from 40 to $52 \%$ ) occurred in the S2 sample. No significant changes in growth parameters were detected in vessel S1 and the vessel with oil-contaminated soil (control).

It is also necessary to note the differences in the parameters of sprouts. In both tests, the average height of coleoptile was lower than in uncontaminated soil, but varied for different bioremediation schemes. The lowest height of sprouts was observed at the oil-contaminated control and did not exceed $2.5 \mathrm{~cm}$. The average cleoptil height for the S2 and S3 schemes was 4.9 and $5.6 \mathrm{~cm}$, respectively, which is about 34.7 and $25.3 \%$ lower than on pure soil.

The data on the effect of oil-contaminated soils on the results of germination energy and seed germination in the studied schemes under laboratory conditions are shown in table 2 .

On the basis of the results of laboratory studies, a field experiment was set up. Winter rye seeds were sown in early August to assess field germination with subsequent wintering and determination of phytomass at the earing stage.

In the field experiment, the results were similar to the results of laboratory studies. The content of petroleum products significantly affected the percentage of germination of rye seeds. There is an inverse dependence of seed germination on the concentration of petroleum hydrocarbons (the higher the concentration, the lower the percentage of germination).

Table 2. Values of germination energy and germination of the Secále cereále seeds under laboratory conditions, $\%$

\begin{tabular}{|l|c|c|c|c|c|}
\hline Days after the spill & Uncontaminated control & Contaminated control & S1 & S2 & S3 \\
\hline 12 days & $\underline{92}$ & $\underline{1}$ & $\frac{10}{25}$ & $\underline{5}$ & $\frac{14}{45}$ \\
\hline \multirow{2}{*}{40 days } & $\underline{88}$ & $\underline{5}$ & $\underline{8}$ & $\underline{16}$ & $\underline{38}$ \\
\hline
\end{tabular}

Note: the numerator is the value of the germination energy, and the denominator is the germination rate. 
Seed germination in sections S2 and S3 of the studied soils did not differ significantly from the control soils that did not contain oil contamination. It is interesting to note that the residual content of petroleum products, which had almost no effect on the germination of winter rye seeds in the bioremediated areas of meadow soils, ranged from 2276 to $2552 \mathrm{mg} / \mathrm{kg}$.

After overwintering in the next growing season, rye went into the earing stage, then the plants were collected and dried at $70^{\circ} \mathrm{C}$ for 3 days to determine the dry weight of plant biomass per site and per plant. The number of plants that entered the earing stage in the "clean" control soil was $57 \%$ of the seeds that sprang up, and in other areas it did not exceed $30 \%$. The average biomass per plant was $97.6 \%$ of the control at site S2, 94\% at site $\mathrm{S} 3,78.8 \%$ at site $\mathrm{S} 1$, and $74 \%$ at the oil contaminated control. The results of the field vegetation experiment are shown in figure 1.

The inhibition of the growth of seeds and sprouts of rye may be due to the toxicity of some petroleum hydrocarbons (Bossert and Bartha, 1985; Chaineau et al., 1996). The oil-contaminated soil becomes hydrophobic, resulting in impaired root and sprout development (Amakiri and Onofeghara, 1983; Udo and Fayemi, 1975) and reduced availability of water and nutrients for crops (Baker, 1970; Klokk, 1984).

The decrease in toxicity at the S3 site may be due to the use of potassium humate. The results showed that humate has a positive effect on the biodegradation of pollution and reduces the incubation time required for the removal of petroleum products. In the presence of humate, higher rates of biodegradation and more intensive growth were observed compared to the cultivation of plants without its addition. Humic acids act as surfactants, helping to release petroleum hydrocarbons into the water environment and thereby enhancing the microbial decomposition processes. A study by Kochany and Smith (2001) found that humic substances can enhance the biotic and abiotic decomposition of phenols, polyaromatic hydrocarbons (PAHs), and pesticides in the aquatic environment. In Kurán̆ et al. (2014), the addition of humates caused only a slight increase in the rate of decomposition of petroleum hydrocarbons, but significantly affected the amount of PLFA in the studied soils, which indicates an improvement in the soil microenvironment. The antidote effect of humates has also been noted in Mosley et al. (1998), Minnikova et al. (2018), and Kim et al. (2018).

a)

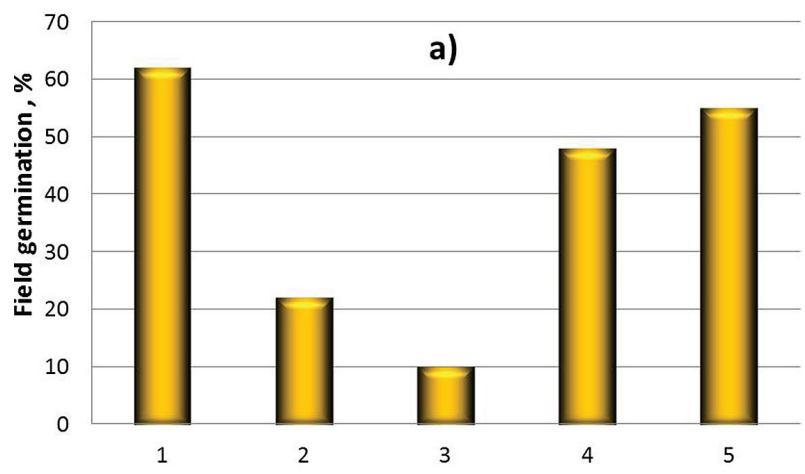

b)

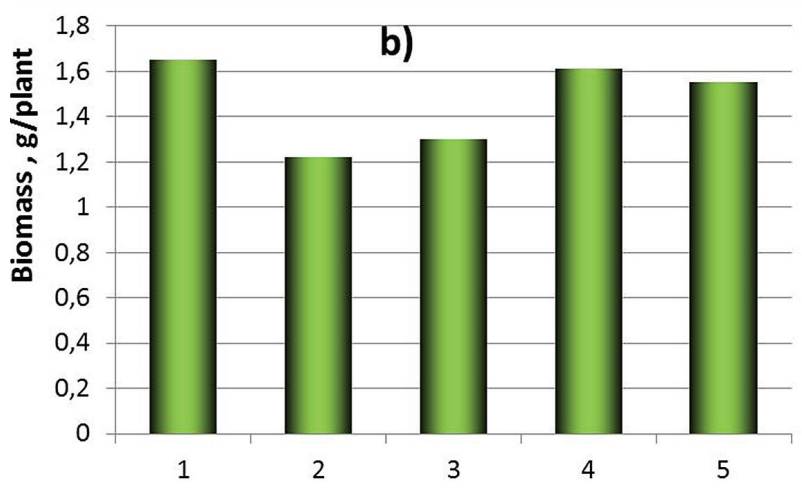

Fig. 1. Average field germination (a) and biomass (b) of the aboveground part of winter rye plants: 1 - uncontaminated control; 2 - oil - contaminated control; 3 - site S1; 4 - site S2; 5-site S3. 
In the $\mathrm{S} 2$ scheme, a vermiculite-based sorbent was used as an auxiliary component. Vermiculite promotes the adsorption of liquids and improves soil aeration (Rhykerd et al., 1999; Embar et al., 2006; Su et al., 2006). In their work, Vasilyeva G.K. et al. (2019), reported that the main mechanisms of the positive action of sorbents are associated with a decrease in the phyto- and microbotoxicity of contaminated soils by reducing the hydrophobicity of soils, increasing their moisture capacity, porosity, and improving the aeration properties. Good aeration not only provides the plant with the necessary oxygen and nitrogen, but also prevents the formation of rot, the development of mold, moss, fungi and various pathogenic microorganisms.

\section{CONCLUSIONS}

The state of vegetation cover under natural conditions is the most important criterion that, along with the content of petroleum products in soils, diagnoses the reversibility of degradation processes and the permissible degree of soil contamination.

The results of the experiments confirm the toxic effect of oil contamination of the soil on the growth and development of plants. It is also necessary to note the differences in the parameters of sprouts. In all tests, the average height of coleoptile was lower than in uncontaminated soil, but differed for different bioremediation schemes.

The limits of Secále cereále's resistance to oil pollution were experimentally determined. The residual content of petroleum products, which had almost no effect on the germination of winter rye seeds in the bioremediated areas of meadow soils, ranged from 2276 to $2552 \mathrm{mg} / \mathrm{kg}$.

The lowest phytotoxicity was observed in the bioremediation schemes using potassium humate and modified vermiculite.

\section{REFERENCES}

1. Kazuya, W. 2001. Microorganisms relevant to bioremediation: Current Opinion in Biotechnology, 237-241.

2. Andreoni, V., \& Gianfreda, L. 2007. Bioremediation and monitoring of aromatic-polluted habitats. Applied Microbiology and Biotechnology, 76(2), 287-308.
3. Robles-González, I.V., Fava, F., \& Poggi-Varaldo, H.M. 2008. A review on slurry bioreactors for bioremediation of soils and sediments. Microbial Cell Factories, 7(1), 5.

4. Lakshmi, M.B., Perumal, V. \& Velan, M. 2013. Bioremediation of phenanthrene by Mycoplana sp. MVMB2 isolated from contaminated soil: Clean Soil Air Water, 41 (1), 86-93.

5. Laurie, A.D. \& LloydJones, G. 1999. Conserved and hybrid meta-cleavage operons from PAHdegrading Burkholderia RP007: Biochem. Biophys. Res. Commun., 262, 308-314.

6. Seo, J.S, Keum, Y.S. \& Li, Q.X. 2009. Bacterial degradation of aromatic compounds: International Journal of Environmental Research and Public Health, 6, 278-309.

7. Lu, J., Dang, Z., Lu, G., Yang, C., Yi, X. \& Guo, C. 2012. Biodegradation Kinetics of Phenanthrene by a Fusant Strain: Current Microbiology, 65(3), 225-230.

8. Lee R.F. 2003. Photo-oxidation and photo-toxicity of crude and refined oils. Spill Science and Technology Bulletin, 8(2), 157-162.

9. Wang W. 1991. Literature review on higher plants for toxicity testing. Water Air Soil Pollut 59, 381-400.

10. Masloboev, V.A., \& Evdokimova, G.A. 2012. Bioremediation of oil product contaminated soils in conditions of North Near-Polar Area. In: Proceedings of the MSTU, Vol. 15, No. 2, pp. 357-360.

11. Pawluśkiewicz B., Gnatowski T., Janicka M. 2020. The influence of soil contamination with diesel oil on germination dynamics and seedling development of selected species of the Fabaceae family. Journal of Ecological Engineering, 21(1), 210-218.

12. Buluktaev A.A. 2019. Fitotoksichnost' neftezagryaznennyh pochv aridnyh territorij (v usloviyah model'nogo eksperimenta). Russian Journal of Ecosystem Ecology, 3, 59-68.

13. Płaza G., Nałecz-Jawecki G., Ulfig K., Brigmon R.L. 2005. The application of bioassays as indicators of petroleum-contaminated soil remediation. Chemosphere, 59, 289-296.

14. Mayer, A.M., \& Poljakoff-Mayber, A. 1982. The Germination of Seeds: Pergamon International Library of Science, Technology, Engineering and Social Studies. Elsevier.

15. Muratova, A.Y., Dmitrieva, T.V., Panchenko, L.V., \& Turkovskaya, O.V. 2008. Phytoremediation of Oil-Sludge-Contaminated Soil. International Journal of Phytoremediation, 10(6), 486-502.

16. Muratova, A.Y., Bondarenkova, A.D., Panchenko, L.V., \& Turkovskaya, O.V. 2010. Use of integrated phytoremediation for cleaning-up of oil-sludgecontaminated soil. Applied Biochemistry and Microbiology, 46(8), 789-794. 
17. Nõlvak, H., Truu, J., Limane, B., Truu, M., Cepurnieks, G., Bartkevičs, V., ... \& Muter, O. 2013. Microbial community changes in TNT spiked soil bioremediation trial using biostimulation, phytoremediation and bioaugmentation. Journal of Environmental Engineering and Landscape Management, 21(3), 153-162.

18. Bossert, I., \& Bartha, R. 1985. Plant growth in soils with a history of oily sludge disposal. Soil Science, 140(1), 75-77.

19. Chaineau, C.H., Morel, J.L., \& Oudot, J. 1996. Land treatment of oil-based drill cuttings in an agricultural soil. Journal of environmental quality, 25(4), 858-867.

20. Amakiri, J.O., \& Onofeghara, F.A. 1983. Effect of crude oil pollution on the growth of Zea mays, Abelmoschus esculentus and Capsicum frutescens. Oil and Petrochemical Pollution, 1(3), 199-205.

21. Udo, E.J., \& Fayemi, A.A.A. 1975. The effect of oil pollution of soil on germination, growth and nutrient uptake of corn. Journal of Environmental Quality, 4(4), 537-540.

22. Baker, J.M. 1970. The effects of oils on plants. Environmental Pollution, 1(1), 27-44.

23. Klokk, T. 1984. Effects of oil pollution on the germination and vegetative growth of five species of vascular plant. Oil and Petrochemical Pollution, 2(1), 25-30.

24. Kochany, J., \& Smith, W. 2001. Application of humic substances in environmental remediation. In: Proceedings of WM'01 Conference, February, Vol. 25.

25. Kuráň, P., Trögl, J., Nováková, J., Pilařová, V., Dáňová, P., Pavlorková, J., ... \& Popelka, J. 2014. Biodegradation of spilled diesel fuel in agricultural soil: Effect of humates, zeolite, and bioaugmentation. The Scientific World Journal, 2014.
26. Mosley, R.A.N.D.Y., \& Morris \& Mosley, I. 1998. The effects of humates on remediation of hydrocarbon and salt contaminated soils. In 5th International Petroleum Environmental Conference, New Mexico, pp. 5-14.

27. Minnikova, T.V., Kolesnikov, S.I., Denisova, T.V., \& Akimenko, Y.V. 2018. Biodiagnosis of the state of oilpolluted chernozem during remediation with urea and potassium humate. International Multidisciplinary Scientific GeoConference: SGEM, 18(3.2), 33-40.

28. Kim, J., Lee, A.H., \& Chang, W. 2018. Enhanced bioremediation of nutrient-amended, petroleum hydrocarbon-contaminated soils over a cold-climate winter: the rate and extent of hydrocarbon biodegradation and microbial response in a pilotscale biopile subjected to natural seasonal freezethaw temperatures. Science of the Total Environment, 612, 903-913.

29. Rhykerd, R.L., Crews, B., McInnes, K.J., \& Weaver, R.W. 1999. Impact of bulking agents, forced aeration, and tillage on remediation of oil-contaminated soil. Bioresource Technology, 67(3), 279-285.

30. Embar, K., Forgacs, C., \& Sivan, A. 2006. The role of indigenous bacterial and fungal soil populations in the biodegradation of crude oil in a desert soil. Biodegradation, 17(4), 369-377.

31. Su, D., Li, P.J., Frank, S. and Xiong, X.Z. 2006. Biodegradation of benzo[a]pyrene in soil by Mucor sp. SF06 and Bacillus sp. SB02 co-immobilized on vermiculite. J. Environ. Sci. 18: 1204-1209

32. Vasilyeva G.K., Strizhakova E.R., Kondrashina V.S., Myazin V.A., Korneikova M.V. 2019. Advantages of the technology of sorption-biological treatment of soils contaminated with oil and oil products. Environmental problems of the northern regions and ways to solve them. 320-321. 